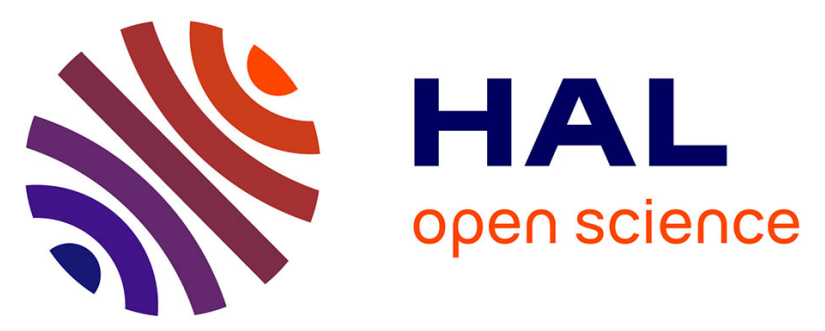

\title{
Screening of fermentative bacteria for their ability to bind and biotransform deoxynivalenol, zearalenone and fumonisins in an in vitro model simulating corn silage
}

Vincent Niderkorn, Diego Morgavi, Estelle Pujos, Antoine Tissandier, Hamid Boudra

\section{To cite this version:}

Vincent Niderkorn, Diego Morgavi, Estelle Pujos, Antoine Tissandier, Hamid Boudra. Screening of fermentative bacteria for their ability to bind and biotransform deoxynivalenol, zearalenone and fumonisins in an in vitro model simulating corn silage. Food Additives and Contaminants, 2007, 24 (04), pp.406-415. 10.1080/02652030601101110 . hal-00577523

\section{HAL Id: hal-00577523 \\ https://hal.science/hal-00577523}

Submitted on 17 Mar 2011

HAL is a multi-disciplinary open access archive for the deposit and dissemination of scientific research documents, whether they are published or not. The documents may come from teaching and research institutions in France or abroad, or from public or private research centers.
L'archive ouverte pluridisciplinaire HAL, est destinée au dépôt et à la diffusion de documents scientifiques de niveau recherche, publiés ou non, émanant des établissements d'enseignement et de recherche français ou étrangers, des laboratoires publics ou privés. 


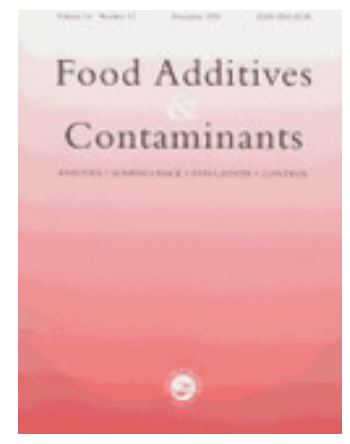

\section{Screening of fermentative bacteria for their ability to bind and biotransform deoxynivalenol, zearalenone and fumonisins in an in vitro model simulating corn silage}

\begin{tabular}{|r|l|}
\hline Journal: & Food Additives and Contaminants \\
\hline Manuscript ID: & TFAC-2006-167.R1 \\
\hline Manuscript Type: & Original Research Paper \\
\hline Author: & 27-Oct-2006 \\
\hline Complete List of Authors: & $\begin{array}{l}\text { Niderkorn, Vincent; French Institute for Agricultural Research } \\
\text { (INRA), Herbivore Research Unit; Lallemand SAS } \\
\text { Morgavi, Diego; French Institute for Agricultural Research (INRA), } \\
\text { Herbivore Research Unit } \\
\text { Pujos, Estelle; French Institute for Agricultural Research (INRA), } \\
\text { Research Unit for Protein-Energy Metabolism } \\
\text { Tissandier, Antoine; French Institute for Agricultural Research } \\
\text { (INRA), Herbivore Research Unit } \\
\text { Boudra, Hamid; French Institute for Agricultural Research (INRA), } \\
\text { Herbivore Research Unit }\end{array}$ \\
\hline Methods/Techniques: & HPLC, LC/MS, Screening - microbial screening \\
\hline Additives/Contaminants: & zearalenone, Fumonisins, Mycotoxins - fusarium, trichothecenes \\
\hline Food Types: & Animal feedingstuffs \\
\hline & \\
\hline
\end{tabular}

\section{SCHOLARONE Manuscripts}


1 Screening of fermentative bacteria for their ability to bind and

2 biotransform deoxynivalenol, zearalenone and fumonisins in an in vitro

3 model simulating corn silage

4

5 V. NIDERKORN ${ }^{1,3}$, D.P. MORGAVI ${ }^{1}$, E. PUJOS $^{2}$, A. TISSANDIER ${ }^{1}$, \& H. $6 \quad$ BOUDRA $^{1}$

7

$8{ }^{1}$ Herbivore Research Unit, French Institute for Agricultural Research (INRA),

9 Clermont-Fd-Theix Research Centre, F-63122 Saint Genès-Champanelle, France

$10{ }^{2}$ Research Unit for Protein-Energy Metabolism, French Institute for Agricultural

11 Research (INRA), Clermont-Fd-Theix Research Centre, F-63122 Saint Genès-

12 Champanelle, France

$13{ }^{3}$ Lallemand S.A.S, 19, rue des briquetiers, B.P. 59, F-31702 Blagnac, France

14

15 Correspondence: VINCENT NIDERKORN e-mail: vniderk@ clermont.inra.fr 16 
19 Abstract

20 Fermentative bacteria can potentially be utilized to detoxify corn silage contaminated by

21 Fusarium toxins. The objective of the present study was to test a large number of these 22 bacteria for their ability to bind and/or biotransform deoxynivalenol (DON), 23 zearalenone $(\mathrm{ZEN})$, and fumonisins $\mathrm{B}_{1}$ and $\mathrm{B}_{2}\left(\mathrm{FB}_{1}, \mathrm{FB}_{2}\right)$ in conditions simulating corn 24 silage. A total of 202 strains were screened in contaminated, $\mathrm{pH} 4$, corn infusion

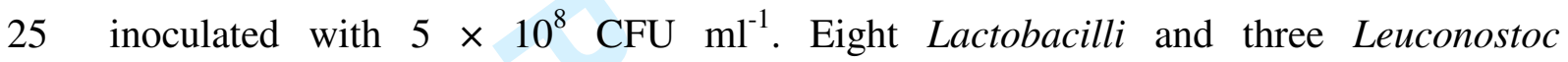
26 biotransformed ZEN into $\alpha$ zearalenol, but no biotransformation was detected for DON 27 and fumonisins. In contrast, most strains were capable of binding Fusarium toxins. The 28 most effective genera were Streptococcus and Enterococcus capable of binding up to $2933 \%, 49 \%, 24 \%$ and $62 \%$ of $\mathrm{DON}, \mathrm{ZEN}, \mathrm{FB}_{1}$ and $\mathrm{FB}_{2}$, respectively. The ability to bind

30 Fusarium toxins seems to be a common property of fermentative bacteria and could 31 help to decrease their toxicity in animals.

33 Keywords: Fusarium, mycotoxins, fermentative bacteria, probiotic, binding, 34 biotransformation, corn silage

36 Running headline: Fusarium toxins removal by fermentative bacteria 


\section{Introduction}

38 Whole-plant corn silage and high moisture, fermented corn grain are widely utilized as 39 ruminants and swine feeds, respectively. Under unfavourable climatic conditions, Fusarium toxins including deoxynivalenol (DON), zearalenone (ZEN), and fumonisins (FB) can be produced on corn plants in the field (Lepom et al. 1990) and be present in silage (Scudamore and Livesey 1998; Orsi et al. 2000). Ingestion of mycotoxincontaminated corn by animals affects performances and health. Among farm animals, swine appear to be most susceptible to the toxic effects of Fusarium toxins, especially to ZEN (Diekman and Green 1992). Although ruminants are considered more resistant,

46 the risk should not be underestimated as data of toxicity after chronic exposure or due to 47 interactions among mycotoxins are limited (Seeling and Danicke 2005). ZEN is 48 associated with estrogenic syndrome and DON causes vomiting in pigs, as well as 49 decreased feed intake and digestive disorders in both pigs and ruminants, leading to losses of weight gain (D'Mello et al. 1999; Eriksen and Pettersson 2004). Fumonisins

51 cause pulmonary edema in swine (Harrison et al. 1990) and hepatotoxicity in ruminants 52 (Diaz et al. 2000).

54 In spite of the progress made in preventive approaches such as breeding of resistant corn varieties (Mesterhazy 1989) and improvement in agronomic practices (Trenholm et al. 1989) to decrease Fusarium contamination, hazardous concentrations of Fusarium 57 toxins may occur in corn justifying the use of detoxification methods. Physical and 58 chemical methods such as ammonia treatment or the addition of adsorbents (Scott 1998;

59 Huwig et al. 2001) are generally expensive, drastic, not specific, or simply not adapted

60 to the treatment of corn destined to livestock. Inorganic adsorbents, although they have 61 a high affinity to bind aflatoxins, are not efficient for Fusarium toxins. In addition, these 
62 agents can also bind important micronutrients like minerals or vitamins (Guerre 2000).

63 Practical methods for the detoxification of silage are currently not available. A

64 promising approach is the use of selected microorganisms to remove Fusarium toxins

65 (Bata and Lasztity 1999). Detoxification can be achieved by microbial binding and/or

66 biotransformation of mycotoxins into less toxic compounds (Styriak and Conkova

67 2002). Due to their role in the ensiling process, fermentative bacteria are appropriate

68 candidates for the biological detoxification of corn silage. The bioconversion of

69 Fusarium toxins by rumen microbes and intestinal microflora was reported (Kiessling et

70 al. 1984; Kollarczik et al. 1994; Caloni et al. 2000) but the bacteria responsible for their

71 biotransformation were not identified. In contrast, binding of DON and ZEN to the cell

72 wall of probiotic strains in vitro has been recently reported (El-Nezami et al. 2002a;

73 2002b). This property can decrease the bioavailability of these compounds by reducing

74 absorption and limit their toxic effects (El-Nezami et al. 1999). However, to date, only

75 three strains were thoroughly investigated. In addition, they were effective at about $10^{10}$

$76 \mathrm{CFU} \mathrm{ml}{ }^{-1}$, a high bacterial concentration that is difficult to obtain in fermented corn 77 feeds.

79 In this study, a large number of strains of fermentative bacteria were screened for their

80 ability to remove DON, $\mathrm{ZEN}, \mathrm{FB}_{1}$ and $\mathrm{FB}_{2}$ from a medium that simulated silage in term

81 of substrate, $\mathrm{pH}$, and bacterial concentration. The test conditions chosen allowed to

82 observe simultaneously binding and/or biotransformation.

83

84 Materials and methods

85 Bacterial strains 
86 Bacterial strains were obtained from different collections (LGC Promochem, Molsheim,

87 France; Research Unit for Food Process Engineering and Microbiology, INRA,

88 Thivernal-Grignon, France; Research Laboratory for Animal Husbandry, INRA, Corte,

89 France; Lallemand SAS, Blagnac, France; Laboratory of Dynamics, Evolution and

90 Expression of Genomes of Microorganisms, University Louis Pasteur/CNRS FRE 2326,

91 Strasbourg, France; Cheese Research Laboratory, INRA, Aurillac, France). A total of

92202 strains were tested: 137 Lactobacilli, 17 Lactococci, 6 Leuconostoc, 2 Pediococci, 5

93 Propionibacteria, 31 Streptococci, and 4 Enterococci. The majority of strains were

94 isolated from dairy and plant material. For long-term conservation, all isolates were

95 stored at $-80^{\circ} \mathrm{C}$ in $30 \%$ glycerol.

96

$97 \quad$ Media

98 De Man, Rogosa, Sharpe broth (MRS, Oxoïd Ltd, Basing-stoke, UK) was used for the

99 culture of Lactobacilli, Pediococci and Leuconostoc. M17 broth (Oxoïd Ltd, Basing-

100 stoke, UK) containing $5 \% \mathrm{v} / \mathrm{v}$ of a $10 \% \mathrm{w} / \mathrm{v}$ lactose solution was used for the culture of

101 Lactococci, Streptococci and Enterococci. Yeast Extract Lactate (YEL) medium,

102 prepared according to Malik and Vedamuthu (1968), was used for the culture of

103 Propionibacteria. A corn infusion was prepared by steeping dry whole-plant corn in

104 water $(6 \% \mathrm{w} / \mathrm{v})$ at $60^{\circ} \mathrm{C}$ for $2 \mathrm{~h}$. The infusion was then filtered through filter paper

105 (Durieux, no. 120, VWR, Fontenay-sous-Bois, France), the filtrate was centrifuged

106 (8500 g, $5 \mathrm{~min}$ ) and the decanted supernatant was filtered through a $0.45 \mu \mathrm{m}$ membrane.

107 The filtered infusion was stored at $4^{\circ} \mathrm{C}$ and adjusted to $\mathrm{pH} 4$ with lactic acid before 108 using.

109

110 Mycotoxins and derivatives 
$111 \mathrm{DON}, \mathrm{FB}_{1}, \mathrm{FB}_{2}, \mathrm{ZEN}$ and its main derivatives $\alpha$ - and $\beta$-zearalenols ( $\alpha$ and $\beta \mathrm{ZOL}$ ), $\alpha$ -

112 and $\beta$-zearalanols ( $\alpha$ - and $\beta$ - ZAL), and zearalanone (ZAN) were purchased from

113 Sigma-Aldrich Chemie Gmbh (Steinheim, Germany). The most common derivative of

114 DON, deepoxy-deoxynivalenol (DOM) was purchased from Biopure (Tulin, Austria).

115 Derivatives of fumonisins, aminopentols $\left(\mathrm{HFB}_{1}\right.$ and $\left.\mathrm{HFB}_{2}\right)$, were obtained by

116 hydrolysis of $\mathrm{FB}_{1}$ and $\mathrm{FB}_{2}$ according to Pagliuca et al. (2005). DON and ZEN (and

117 derivatives) were dissolved in acetonitrile and methanol, respectively. Concentration

118 was determined by measuring the absorbance at $218 \mathrm{~nm}$ for DON $\left(\varepsilon=6406 \mathrm{mmol}^{-1}\right.$

$\left.119 \mathrm{~cm}^{2}\right)$ and at $274 \mathrm{~nm}$ for ZEN $\left(\varepsilon=13909 \mathrm{mmol}^{-1} \mathrm{~cm}^{2}\right)$. Since spectrophotometry is not

120 possible with $\mathrm{FB}_{1}$ and $\mathrm{FB}_{2}$, these compounds were dissolved in an exact volume of

121 acetonitrile-water 1:1(v/v) to achieve the desired concentration. Mycotoxin solutions of

122 DON $\left(5 \mu \mathrm{g} \mathrm{ml}^{-1}\right)$, ZEN $\left(5 \mu \mathrm{g} \mathrm{ml}^{-1}\right), \mathrm{FB}_{1}+\mathrm{FB}_{2}\left(5 \mu \mathrm{g} \mathrm{ml} l^{-1}\right.$ each $)$ in corn infusion were

123 prepared by evaporating solvents with nitrogen gas, redissolving in water (DON, $\mathrm{FB}_{1}$,

$124 \mathrm{FB}_{2}$ ) or ethanol (ZEN) and adding corn infusion to reach the desired concentration. The

125 water or ethanol solvent represented $5 \%(\mathrm{v} / \mathrm{v})$ of the final mycotoxin solution.

127 Mycotoxin removal test

128 Bacteria screened for their ability to bind and/or biotransform Fusarium toxins were

129 prepared as follow. For each strain, one tube containing $20 \mathrm{ml}$ of medium was

130 inoculated with $0.1 \mathrm{ml}$ of an overnight culture and was incubated at optimal temperature

131 of growth $\left(30\right.$ or $\left.37^{\circ} \mathrm{C}\right)$ for 24 h. Propionibacteria strains were incubated at $30^{\circ} \mathrm{C}$ for 72

$132 \mathrm{~h}$. At the end of incubation, the bacterial concentration of cultures was estimated by

133 measuring the absorbance at $600 \mathrm{~nm}$ as described previously (Niderkorn et al. 2006). A

134 volume of culture containing $35 \times 10^{8} \mathrm{CFU}$ was centrifuged $\left(3000 \mathrm{~g}, 10 \mathrm{~min}, 5^{\circ} \mathrm{C}\right)$ and

135 the supernatant was removed. The bacterial pellet was washed twice with $5 \mathrm{ml}$ of 
136 phosphate-buffered saline (PBS 0.01 M, pH 7.4). After the second wash, the bacterial

137 pellet was resuspended in $7 \mathrm{ml}$ PBS to obtain a concentration of $5 \times 10^{8} \mathrm{CFU} \mathrm{ml}^{-1}$, and 138 transferred to six polypropylene tubes ( $1 \mathrm{ml}$ per tube). Tubes were centrifuged (3000 g, $13910 \mathrm{~min}, 5^{\circ} \mathrm{C}$ ), supernatants were removed, and bacteria were re-suspended in $1 \mathrm{ml}$ of 140 one of the three mycotoxin solutions. Positive controls containing no bacteria and a 141 negative control per bacterial genus containing no mycotoxin were included. All the 142 tubes were incubated at $25^{\circ} \mathrm{C}$ in microaerophilic conditions for $1 \mathrm{~h}$ with shaking (480 $143 \mathrm{rpm}$ ), then for $23 \mathrm{~h}$ without shaking. At the end of the incubation period, tubes were 144 centrifuged $\left(3000 \mathrm{~g}, 10 \mathrm{~min}, 5^{\circ} \mathrm{C}\right.$ ) and supernatants were analysed for mycotoxins by 145 reversed-phase HPLC. Assays and positive controls were performed in duplicate.

146 The percentage of mycotoxin removed was calculated by using the following 147 formula: Mycotoxin removed $(\%)=100 \times[1-($ Peak area of mycotoxin in the 148 supernatant / Peak area of mycotoxin in the positive control)].

\section{HPLC mycotoxins analysis}

151 Separation and quantification of mycotoxins were performed by the method described 152 previously (Niderkorn et al. 2006) with slight modifications in order to remove 153 interferences. The HPLC system consisted of a P1000XR pump (SpectraSYSTEM, San 154 Jose, California, USA) and an automatic sampler (SpectraPhysics, San Jose, California, 155 USA). Separation was performed on $\mathrm{C}_{18}$ reversed-phase columns (Macherey-Nagel, 156 France); Nucleodur $(125 \times 4.6 \mathrm{~mm}, 5 \mathrm{~mm})$ was used for DON and ZEN and Prontosil $157(120 \times 3.0 \mathrm{~mm}, 3 \mu \mathrm{m})$ was used for $\mathrm{FB}_{1}$ and $\mathrm{FB}_{2}$. The mobile phase used to separate 158 DON consisted of a water-acetonitrile solution $(95: 5 \mathrm{v} / \mathrm{v})$ and the flow rate was $1 \mathrm{ml}$ $159 \mathrm{~min}^{-1}$. Detection was set at $220 \mathrm{~nm}$ and retention time was $12.1 \mathrm{~min}$. After $14 \mathrm{~min}$ of 160 run, the column was washed with a water-acetonitrile solution $(80: 20 \mathrm{v} / \mathrm{v})$ to remove 
161 interferences and was equilibrated with the mobile phase for 6 min before the following

162 injection. The mobile phase used to separate ZEN consisted of a water-methanol

163 solution $(40: 60 \mathrm{v} / \mathrm{v})$ and the flow rate was $1.2 \mathrm{ml} \mathrm{min}^{-1}$. ZEN was detected by photo-

164 diode-array (scan $200-380 \mathrm{~nm})$ and fluorescence $\left(\lambda_{\mathrm{exc}}=274 \mathrm{~nm}, \lambda_{\mathrm{em}}=440 \mathrm{~nm}\right)$ placed

165 in series. The retention time of ZEN was 10.7 min. Fumonisins were derivatized before

166 injection using ortho-phtalaldehyde (OPA) plus mercaptoethanol. Ten $\mu 1$ of sample

167 were mixed with $90 \mu \mathrm{l}$ of borate buffer $\mathrm{pH} 10$, then $100 \mu \mathrm{l}$ of derivatizing reagent were

168 added. The preparation was mixed and allowed to react for $2 \mathrm{~min}$ before injection.

169 Separation of $\mathrm{FB}_{1}$ and $\mathrm{FB}_{2}$ was performed with a gradient elution using acetonitrile (A)

170 and a mixture of $0.05 \mathrm{~mol} \mathrm{l}^{-1}$ dihydrogen phosphate-methanol $(1: 1 \mathrm{v} / \mathrm{v})$ acidified at $\mathrm{pH}$

1713.35 (B). The gradient program was as follows: $10 \%$ to $50 \% \mathrm{~A}$ in $6 \mathrm{~min}, 50 \% \mathrm{~A}$ for 7

$172 \mathrm{~min}$, and $50 \%$ to $10 \% \mathrm{~A}$ in $1 \mathrm{~min}$. The flow rate was $1 \mathrm{ml} \mathrm{min}{ }^{-1}$ and detection was set at

$173336 \mathrm{~nm}$ excitation and $440 \mathrm{~nm}$ emission. The retention times were 10.0 and $12.7 \mathrm{~min}$ for

$174 \quad \mathrm{FB}_{1}$ and $\mathrm{FB}_{2}$, respectively.

175

176 HPLC-ESI-MS/MS analysis

177 A HPLC-MS/MS (TSQ Quantum Ultra AM, Thermo Electron, San Jose, California,

178 USA) equipped with an electrospray ionization source (ESI) interface operating in the

179 negative mode was used to identify the ZEN derivative produced by some strains.

180 Chromatographic separation and MS analysis was performed on a $125 \times 4.6 \mathrm{~mm}$

181 Prontosil $\mathrm{C}_{18}$ column with particle size of $3 \mu \mathrm{m}$ (Bischoff, Leonberg, Germany), using a

182 methanol $-1 \%$ acetic acid $(65: 35 \mathrm{v} / \mathrm{v})$ mobile phase at a flow rate of $0.8 \mathrm{ml} \mathrm{min} \mathrm{m}^{-1}$.

183 Parameters of the MS were optimised using standard solutions of $\alpha$ ZOL in mobile

184 phase. The test responses were recorded with electrospray voltage $3.0 \mathrm{kV}$, capillary

185 temperature $400^{\circ} \mathrm{C}$, sheath flow and auxiliary flow 50 and 10 arbitrary units, 
186 respectively. Multiple reaction monitoring (MRM) was used to identify the metabolite.

187 The most intense transitions from the fragmentation of ZEN, $\alpha$ ZOL and ZAN were 188 determined. Six product ions were selected at different collision energies (CE) so as to 189 characterize each molecule of interest (Table I). For analysis, $4 \mathrm{ml}$ of corn infusion 190 sample were extracted with $4 \mathrm{ml}$ dichloromethane. The mixture was mixed for $15 \mathrm{~min}$ 191 then centrifuged at $3000 \mathrm{~g}$ for $10 \mathrm{~min}$. One $\mathrm{ml}$ of the organic layer was transferred into a 192 new tube and evaporated to dryness under a stream of $\mathrm{N}_{2}$. The dried residue was 193 redissolved in $200 \mu \mathrm{l}$ of mobile phase, and $5 \mu \mathrm{l}$ of this solution were injected into the

194 HPLC-MS/MS system. MS-analysis of extract was compared with ZEN, $\alpha$ ZOL and 195 ZAN standards. [Insert Table I about here]

197 Statistical analysis

198 Data was subjected to the analysis of variance (ANOVA). A significant difference $(p<$ 199 0.05) between means was determined by Duncan's multiple range test using the 200 Statistical Analysis System software package (SAS Institute Inc., Cary, NC).

202 Results

203 The experimental model used in this work allowed us to observe at the same time

204 biotransformation and binding of Fusarium toxins by fermentative bacteria. The HPLC 205 method used, separated each mycotoxin as well as their main derivatives from the corn 206 infusion medium matrix without an extraction step (Figure 1) and thus facilitated the 207 screening. [Insert Figure 1 about here] 208 209 Biotransformation of mycotoxins 
210 In incubations containing DON and fumonisins no biotransformation products were

211 observed. There were not peaks corresponding to DOM and aminopentol—derivatives

212 of DON and fumonisins, respectively-or any other unknown peak in the HPLC

213 chromatograms. In contrast, in incubations containing ZEN for 11 out of the 202 strains

214 tested (about 5.5\%), an additional peak was observed in the chromatograms. This peak

215 had the same retention time for all 11 strains suggesting that it was the same metabolite

216 (Figure 2). Eight out of the 11 strains were Lactobacilli and the other three were

217 Leuconostoc. These biotransforming Lactobacilli removed approximately twice more

218 ZEN from the incubation media than strains from the same genus that only bound the

219 mycotoxin (Table II and III). [Insert Figure 2 and Table II about here]

221 The ZEN metabolite showed a UV spectrum similar to ZEN with absorption maxima at 222 236, 274, and $316 \mathrm{~nm}$ (Figure 2, inset). Retention time (Rt) of this peak was compared 223 to those of main ZEN derivatives using modified chromatographic conditions to 224 improve separation. The changes in the chromatography were in the mobile phase, 225 which consisted in methanol $-1 \%$ acetic acid mixture $(65: 35 \mathrm{v} / \mathrm{v})$, and the flow rate, 226 which was set at $0.8 \mathrm{ml} \mathrm{min}^{-1}$. Under these conditions, the Rt of the unknown metabolite 227 was $9.56 \mathrm{~min}$, similar to $\alpha$ ZOL (9.50 min), while Rts of $\beta$ ZOL, $\alpha$ and $\beta$ ZAL, and ZAN 228 standards were $6.10,7.74,4.35$, and $9.84 \mathrm{~min}$, respectively. This result indicated that $\alpha$ 229 ZOL was most likely the metabolite produced. The Rt of ZAN was also near to that of 230 the unknown metabolite. However, ZAN, at a concentration of $5 \mu \mathrm{g} \mathrm{ml}^{-1}$ had a peak 231 area considerably lower than the peak area of the metabolite produced by active 232 bacterial strains incubated with an equal concentration of ZEN and hence ZAN was 233 unlikely the searched compound. Additional HPLC-MS/MS analyses were performed 234 on ZEN-containing corn infusion extracts after incubation with biotransforming strains. 
235 The LC-MS showed that the new peak had the same mass transitions characteristic $(\mathrm{m} / \mathrm{z}$ $236=319$ ) as $\alpha$ ZOL (Figure 3) and thus unequivocally identified the metabolite. [Insert

237 Figure 3 about here]

238

239 Binding of zearalenone, deoxynivalenol and fumonisins from acidified corn infusion

240 Table III shows the mycotoxin-binding capacity of the tested fermentative bacteria

241 grouped by genera. Across all genera, $\mathrm{FB}_{2}$ was the mycotoxin most efficiently removed

242 followed by ZEN, DON, and $\mathrm{FB}_{1}$. The average fraction of DON bound by the different

243 genera ranged from 15 to $22 \%$ but these differences were not significant $(p>0.05)$. In

244 contrast, large differences among genera were observed for the binding of ZEN and

245 fumonisins $(p<0.05)$. It is interesting to note that, independently of the molecular

246 structure of these mycotoxins, the genera Streptococcus and Enterococcus ranked

247 always as the most efficient binders under the conditions of the assay. In particular,

248 strains of Streptococcus thermophilus, which bound up to 49\%, 33\%, 24\%, and $62 \%$ of

249 ZEN, DON, $\mathrm{FB}_{1}$ and $\mathrm{FB}_{2}$, respectively. Out of the 202 strains tested about two third

250 were Lactobacilli. This apparent bias has a biotechnological explanation because

251 species of this genus are very active during the ensiling process and hence widely used

252 as inoculants. Lactobacilli are dominant members of the bacterial population found in

253 grass and corn silages (Langston and Bouma 1960; Dellaglio and Torriani 1986). L.

254 plantarum, of which we tested 46 isolates, is a particularly common epiphytic specie,

255 which is also found in many commercial silage additives (Weinberg and Muck 1996).

256 All the other selected strains used in this work are representative of genera of 257 fermentative bacteria regularly associated with silage (Moon et al. 1981; Driehuis and

258 Elferink 2000). The binding activities of Lactobacillus spp. are shown in Table IV.

259 Significant differences were observed among strains; however, compared to 
260 Streptococcus and Enterococcus strains the binding capacity of the Lactobacilli was less

261 important. [Insert Table III and Table IV about here]

262

\section{Discussion}

264 The ability of fermentative bacteria to biotransform or bind Fusarium toxins in whole-

265 plant corn silage and fermented corn grain is a promising way to reduce their toxic

266 effects on livestock. In this work, the conditions used to screen fermentative bacteria

267 permitted to observe simultaneously binding and biotransformation in a liquid medium

268 representative of corn silage.

270 The reduction of ZEN into $\alpha$-ZOL can be carried out in the liver and also by the flora 271 harboured in the digestive tract of animals (Olsen and Kiessling 1983; Kiessling et al. 272 1984; Kollarczik et al. 1994). However, it had never been observed with pure strains of 273 lactic acid bacteria (LAB). In this study, this biotransformation was observed in 11 274 strains but it cannot be considered as a detoxification because $\alpha$-ZOL is three to four 275 times more estrogenic than ZEN (Mirocha et al. 1979). All the positive bacterial strains 276 detected in this work were capable to produce large quantities of $\alpha$-ZOL from ZEN. 277 Even if strains possessing this property represent a relatively low percentage of the total 278 fermentative bacteria, they could form part of the epiphytic population present in 279 fermented feeds and convert significant amounts of ZEN into $\alpha$-ZOL. This means that 280 the absence of ZEN or its presence in non toxic concentrations does not guarantee feed 281 innocuity, and therefore, it could be advisable to check for the presence of $\alpha$-ZOL in 282 fermented feeds. It could also be recommended to check if this property is not present in 283 strains used as fermentation starters. The biotransformation of ZEN to $\alpha$-ZOL might 284 explain the results of a recent study where a significant decrease in the concentration of 
285 ZEN was observed during the fermentation of corn meal by LAB but without a

286 reduction in toxicity (Mokoena et al. 2005).

287

288 Binding of mutagens and mycotoxins by LAB was reported in numerous studies 289 (Morotomi and Mutai 1986; El-Nezami et al. 1998). Binding of DON and ZEN by three 290 probiotic strains was also recently reported, but they were not effective at the low 291 densities found in fermented corn feeds (El-Nezami et al. 2002a; 2002b). The results of 292 the present work showed that significant quantities of Fusarium toxins including 293 fumonisins are bound by most species of fermentative bacteria at a density of $5 \times 10^{8}$ $294 \mathrm{CFU} \mathrm{ml}{ }^{-1}$. We also confirmed previous observations (Niderkorn et al. 2006) showing 295 that $\mathrm{FB}_{2}$ was removed more efficiently than $\mathrm{FB}_{1}$ in spite of their similarity in chemical 296 structure.

298 Since most strains of fermentative bacteria tested seem to have the ability to bind DON, 299 ZEN and fumonisins, it is probable that these Fusarium toxins are also partially bound 300 by the epiphytic microflora of silage or by inoculants already utilized to improve silage 301 fermentation or aerobic stability. Although Lactobacilli are widely utilized as silage 302 additives, none of the strains tested was particularly efficient at binding Fusarium 303 toxins. From the isolates tested in this work, the use of fermentative bacteria to bind 304 Fusarium toxins in silage appear to be more advantageous for Streptococci and 305 Enterococci, which bound more ZEN and fumonisins than other genera. Consequently, 306 an advantageous use of fermentative bacteria to bind Fusarium toxins in silage would 307 be limited to these two genera. The higher capacity to bind Fusarium toxins by 308 Streptococci and Enterococci cannot be explained by their size as they are smaller than 309 other genera with lower binding capacity such as Lactobacillus. The composition of the 
310 cell wall may confer the Streptococci and Enterococci their superior binding property.

311 The mechanism of binding of mycotoxins by bacteria is still not clear. In the case of 312 ZEN, it was recently suggested that this mycotoxin predominantly binds to

313 carbohydrate moieties of the cell wall of LAB by means of hydrophobic interactions 314 (El-Nezami et al. 2004). As hydrophobic interactions are relatively weak, this 315 bacterium-mycotoxin complex could be unstable. Nevertheless, these authors also 316 suggested that ZEN binding is not limited to hydrophobic links and other type of 317 interactions could be important.

\section{Conclusions}

320 The use of selected strains of fermentative bacteria could be a method to limit the toxic 321 effects of Fusarium toxins present in corn silage. Our results have shown that the 322 biodegradation of mycotoxins is possible. However, the resulting compound is not 323 always less toxic than the parent mycotoxin. Binding seems to be the most promising 324 mode of action, but for the practical application of this technology, it is essential that the 325 bacterium-mycotoxin complex remain stable during the digestion process. Further 326 studies are planned to evaluate the stability of the complex in the different parts of the 327 gastrointestinal tract of farm animals.

330 Acknowledgements

331 V. Niderkorn is the recipient of a CIFRE Lallemand SAS research fellowship. The 332 authors are thankful to the Research Unit for Food Process Engineering and 333 Microbiology, INRA Thivernal-Grignon, France, the Research Laboratory for Animal 334 Husbandry, INRA Corte, France, the Laboratory of Dynamics, Evolution and 
335 Expression of Genomes of Microorganisms, University Louis Pasteur/CNRS FRE 2326,

336 Strasbourg, France, the Cheese Research Laboratory, INRA, Aurillac, France, and

337 Lallemand SAS, Blagnac, France, for providing the strains of fermentative bacteria.

338 They also thank Henri Durand, Frederique Chaucheyras-Durand, and Corinne Pouyet

339 for the scientific assistance in this project. 


\section{References}

Bata A, Lasztity R. 1999. Detoxification of mycotoxin-contaminated food and feed by microorganisms. Trends in Food Science and Technology 10:223-228.

Caloni F, Spotti M, Auerbach H, Op den Camp H, Gremmels JF, Pompa G. 2000. In vitro metabolism of fumonisin B1 by ruminal microflora. Veterinary Research Communications 24:379-387.

Dellaglio F, Torriani S. 1986. DNA-DNA homology, physiological characteristics and distribution of lactic acid bacteria isolated from maize silage. Journal of Applied Bacteriology 60:83-92.

Diaz D, Hopkins B, Leonard L, Hagler W, Whitlow LW. 2000. Effect of fumonisin on lactating dairy cattle. Journal of Dairy Science 83:1171(Abstr.).

Diekman MA, Green ML. 1992. Mycotoxins and reproduction in domestic livestock. Journal of Animal Science 70:1615-1627.

D'Mello JPF, Placinta CM, Macdonald AMC. 1999. Fusarium mycotoxins: a review of global implications for animal health, welfare and productivity. Animal Feed Science and Technology 80:183-205.

Driehuis F, Elferink S. 2000. The impact of the quality of silage on animal health and food safety: A review. Veterinary Quarterly 22:212-216.

El-Nezami H, Chrevatidis A, Auriola S, Salminen S, Mykkanen H. 2002a. Removal of common Fusarium toxins in vitro by strains of Lactobacillus and Propionibacterium. Food Additives and Contaminants 19:680-686.

El-Nezami H, Kankaanpaa P, Salminen S, Ahokas J. 1998. Ability of dairy strains of lactic acid bacteria to bind a common food carcinogen, aflatoxin B1. Food and Chemical Toxicology 36:321-326. 
El-Nezami H, Mykkanen H, Kankaanpaa P, Salminen S, Ahokas J. 1999. Ability of Lactobacillus and Propionibacterium strains to remove aflatoxin B1, from the chicken duodenum. Journal of Food Protection 63:549-552.

El-Nezami H, Polychronaki N, Lee YK, Haskard C, Juvonen R, Salminen S, Mykkanen H. 2004. Chemical moieties and interactions involved in the binding of zearalenone to the surface of Lactobacillus rhamnosus strains GG. Journal of Agricultural and Food Chemistry $52: 4577-4581$

El-Nezami H, Polychronaki N, Salminen S, Mykkanen H. 2002b. Binding rather than metabolism may explain the interaction of two food-Grade Lactobacillus strains with zearalenone and its derivative alpha-zearalenol. Applied and Environmental Microbiology 68:3545-3549.

Eriksen GS, Pettersson H. 2004. Toxicological evaluation of trichothecenes in animal feed. Animal Feed Science and Technology 114:205-239.

Guerre P. 2000. Interest of the treatments of raw materials and usage of adsorbents to decontaminate animal food containing mycotoxins. Revue de Medecine Veterinaire 151:1095-1106.

Harrison LR, Colvin BM, Greene JT, Newman LE, Cole JR. 1990. Pulmonary edema and hydrothorax in swine produced by fumonisin B1, a toxic metabolite of Fusarium moniliforme. Journal of Veterinary Diagnostic Investigation 2:217-221.

Huwig A, Freimund S, Kappeli O, Dutler H. 2001. Mycotoxin detoxication of animal feed by different adsorbents. Toxicology Letters 122:179-188.

Kiessling KH, Pettersson H, Sandholm K, Olsen M. 1984. Metabolism of aflatoxin, ochratoxin, zearalenone, and three trichothecenes by intact rumen fluid, rumen protozoa, and rumen bacteria. Applied and Environmental Microbiology 47:1070-1073. 
Kollarczik B, Gareis M, Hanelt M. 1994. In vitro transformation of the Fusarium mycotoxins deoxynivalenol and zearalenone by the normal gut microflora of pigs. Natural Toxins 2:105110.

Langston CW, Bouma C. 1960. A study of the microorganisms from grass silage. II. The Lactobacilli. Applied Microbiology 8:223-234.

Lepom P, Knabe O, Baath H. 1990. Occurrence of Fusarium species and their mycotoxins in maize. 6. Formation of zearalenone and trichothecenes type A by indigenous Fusarium isolates. Archives of Animal Nutrition 40:871-883.

Malik AC, Reinbold GW, Vedamuthu ER. 1968. An evaluation of the taxonomy of Propionibacterium. Canadian Journal of Microbiology 14:1185-91.

Mesterhazy A.1989. Progress in breeding of wheat and corn genotypes not susceptible to infection by fusaria. In: Fusarium: mycotoxins, taxonomy and pathogenicity. Chelkowski J. Elsevier Science Publishers B. V. Amsterdam, Netherlands. pp 357-377.

Mirocha CJ, Schauerhamer B, Christensen CM, Niku-Paavola ML, Nummi M. 1979. Incidence of zearalenol (Fusarium mycotoxin) in animal feed. Applied and Environmental Microbiology 38:749-750.

Mokoena MP, Chelule PK, Gqaleni N. 2005. Reduction of fumonisin B1 and zearalenone by lactic acid bacteria in fermented maize meal. Journal of Food Protection 68:2095-2099.

Moon NJ, Moon LC, Ely LO, Parker JA. 1981. Lactic acid bacteria active during the fermentation of wheat silage in small scale silos. European Journal of Applied Microbiology and Biotechnology 13:248-250.

Morotomi M, Mutai M. 1986. In vitro binding of potent mutagenic pyrolysates to intestinal bacteria. Journal of the National Cancer Institute 77:195-201.

Niderkorn V, Boudra H, Morgavi DP. 2006. Binding of Fusarium mycotoxins by fermentative bacteria in vitro. Journal of Applied Microbiology 101:849-856. 
Olsen M, Kiessling KH. 1983. Species differences in zearalenone-reducing activity in subcellular fractions of liver from female domestic animals. Acta Pharmacologica et Toxicologica 52:287-291.

Orsi RB, Correa B, Possi CR, Schammass EA, Nogueira JR, Dias SMC, Malozzi MAB. 2000. Mycoflora and occurrence of fumonisins in freshly harvested and stored hybrid maize. Journal of Stored Products Research 36:75-87.

Pagliuca G, Zironi E, Ceccolini A, Matera R, Serrazanetti GP, Piva A. 2005. Simple method for the simultaneous isolation and determination of fumonisin B1 and its metabolite aminopentol-1 in swine liver by liquid chromatography-fluorescence detection. Journal of Chromatography B 819:97-103.

Scott PM. 1998. Industrial and farm detoxification processes for mycotoxins. Revue de Medecine Veterinaire 149:543-548.

Scudamore KA, Livesey CT. 1998. Occurrence and significance of mycotoxins in forage crops and silage: a review. Journal of the Science of Food and Agriculture 77:1-17.

Seeling K, Danicke S. 2005. Relevance of the Fusarium toxins deoxynivalenol and zearalenone in ruminant nutrition. A review. Journal of Animal and Feed Sciences 14:3-40.

Styriak I, Conkova E. 2002. Microbial binding and biodegradation of mycotoxins. Veterinary and Human Toxicology 44:358-361.

Trenholm HL, Prelusky DB, Young JC, Miller JD. 1989. A practical guide to the prevention of Fusarium mycotoxins in grain and animal feedstuffs. Archives of Environmental Contamination and Toxicology 18:443-451.

Weinberg ZG, Muck RE. 1996. New trends and opportunities in the development and use of inoculants for silage. FEMS Microbiology Reviews 19:53-68. 


\section{Table captions}

Table I. Product ions of zearalenone (ZEN), $\alpha$ zearalenol ( $\alpha$ ZOL), and zearalanone (ZAN) for HPLC-ESI-MS/MS analysis.

Table II. Lactic acid bacteria biotransforming zearalenone (ZEN) to $\alpha$ zearalenol ( $\alpha$ ZOL).

Table III. In vitro binding of zearalenone (ZEN), deoxynivalenol (DON), and fumonisins $\mathrm{B}_{1}$ and $\mathrm{B}_{2}\left(\mathrm{FB}_{1}, \mathrm{FB}_{2}\right)$ by different genera of fermentative bacteria.

Table IV. In vitro binding of zearalenone, deoxynivalenol, and fumonisins $\mathrm{B}_{1}$ and $\mathrm{B}_{2}$ by Lactobacillus species.

\section{Figure captions}

Figure 1. HPLC chromatograms of corn infusion supernatants incubated with bacteria $(5 \times$ $10^{8} \mathrm{CFU} \mathrm{ml} l^{-1}$ ) at $25^{\circ} \mathrm{C}$ for $24 \mathrm{~h}$ without and with zearalenone (ZEN, $5 \mu \mathrm{g} \mathrm{ml}^{-1}$ ) (a), without and with fumonisins $\mathrm{B}_{1}$ and $\mathrm{B}_{2}\left(\mathrm{FB}_{1}\right.$ and $\mathrm{FB}_{2}, 5 \mu \mathrm{g} \mathrm{m}{ }^{-1}$ each) (b), without and with deoxynivalenol (DON, $5 \mu \mathrm{g} \mathrm{ml}^{-1}$ ) (c).

Figure 2. HPLC chromatograms of corn infusion supernatants containing zearalenone (ZEN, 5 $\mu \mathrm{g} \mathrm{ml}^{-1}$ ) incubated at $25^{\circ} \mathrm{C}$ for $24 \mathrm{~h}$ without bacteria (a) and with Lactobacillus brevis $\mathrm{R} 0002$ $\left(5 \times 10^{8} \mathrm{CFU} \mathrm{m}{ }^{-1}\right)(\mathrm{b}) . \mathrm{ZEN}($ retention time $=10.4 \mathrm{~min})$ and metabolite (retention time $=9.2$ min) showed a similar UV spectrum (inset).

Figure 3. HPLC-MS spectra of zearalenone, ZEN (a) and $\alpha$ zearalenol, $\alpha$ ZOL (b) standards alone, and the extract from corn infusion supernatant containing ZEN and the produced metabolite (c). Spectra of peaks 1 and 2 showed parent mass of m/z 319.08 and 317.06, respectively. 
Table I. Product ions of zearalenone (ZEN), $\alpha$ zearalenol ( $\alpha$ ZOL), and zearalanone (ZAN) for HPLC-ESI-MS/MS analysis

\begin{tabular}{llll}
\hline Compound & Retention time $(\mathrm{min})$ & Transition & $\mathrm{CE}(\mathrm{V})$ \\
\hline ZEN & 11.01 & $317 \rightarrow 130$ & 46 \\
& $317 \rightarrow 131$ & 35 \\
& $317 \rightarrow 149$ & 35 \\
& $317 \rightarrow 175$ & 34 \\
& $317 \rightarrow 187$ & 30 \\
& $317 \rightarrow 273$ & 27 \\
\hline a-ZOL & 9.59 & $319 \rightarrow 130$ & 54 \\
& & $319 \rightarrow 131$ & 55 \\
& $319 \rightarrow 160$ & 37 \\
& $319 \rightarrow 174$ & 13 \\
& $319 \rightarrow 275$ & 31 \\
\hline ZAN & $319 \rightarrow 301$ & 27 \\
\hline & $319 \rightarrow 137$ & 52 \\
& & $319 \rightarrow 161$ & 35 \\
& & $319 \rightarrow 163$ & 38 \\
& $319 \rightarrow 205$ & 31 \\
& & $319 \rightarrow 259$ & 37 \\
& & $319 \rightarrow 275$ & 28 \\
\hline
\end{tabular}


Table II. Lactic acid bacteria biotransforming zearalenone (ZEN) to $\alpha$ zearalenol ( $\alpha$ ZOL) ${ }^{*}$

\begin{tabular}{llll}
\hline Taxon & Source & Used in & ZEN biotransformed (\%) \\
\hline Lactobacillus & & & $41(1)$ \\
L. brevis & LGMPA - C11 & Cheese making & $47(2)$ \\
L. brevis & Lallemand - R0002 & Animal nutrition & $24(1)$ \\
L. brevis & Lallemand - L62 & Baking & $49(4)$ \\
L. casei casei & LGMPA - B1 & Cheese making & $19(0)$ \\
L. fermenti & LGMPA - 34 & Cheese making & $41(2)$ \\
L. plantarum & LGMPA - J1 & Cheese making & $50(3)$ \\
L. plantarum & Lallemand - R1113 & Baking & $23(1)$ \\
L. spp. & LGMPA - F7 & Cheese making & $16(2)$ \\
Leuconostoc & & & $8(0)$ \\
Ln. mesenteroides or Ln. pseudomesenteroides & URF - 171 & Cheese making & $9(0)$ \\
Ln. mesenteroides or Ln. pseudomesenteroides & URF - 365 & Cheese making & Cheese making \\
Ln. mesenteroides & URF - 1118 & &
\end{tabular}

*Bacteria $\left(5 \times 10^{8} \mathrm{CFU} \mathrm{ml}{ }^{-1}\right)$ were incubated for $24 \mathrm{~h}$ at $25^{\circ} \mathrm{C}$ in corn infusion, $\mathrm{pH} 4$, containing ZEN $(5 \mu \mathrm{g}$ $\left.\mathrm{ml}^{-1}\right)$. Data shown are the means (SD) of duplicate. 
Table III. In vitro binding of zearalenone (ZEN), deoxynivalenol (DON), and fumonisins $\mathrm{B}_{1}$ and $\mathrm{B}_{2}\left(\mathrm{FB}_{1}, \mathrm{FB}_{2}\right)$ by different genera of fermentative bacteria*

\begin{tabular}{|c|c|c|c|c|c|}
\hline \multirow{3}{*}{$\begin{array}{l}\text { Genus } \\
\text { Enterococcus }\end{array}$} & \multirow{3}{*}{$\begin{array}{c}\text { Number of strains } \\
4\end{array}$} & \multicolumn{4}{|c|}{ Fraction bound $(\%)^{\dagger}$} \\
\hline & & $\mathrm{ZEN}^{\ddagger}$ & DON & FB1 & FB2 \\
\hline & & $35(2)^{c}$ & $22 \quad(8)$ & $14(7)^{b}$ & $43(8)^{b}$ \\
\hline Lactobacillus & 137 & $20 \quad(4)^{b}$ & $15 \quad(9)$ & $10(6)^{a b}$ & $24(11)^{a}$ \\
\hline Lactococcus & 17 & $17(4)^{a b}$ & $18 \quad(8)$ & $11\left(^{a b}\right)^{a b}$ & $19(8)^{a}$ \\
\hline Leuconostoc & 6 & $28 \quad(7)^{b c}$ & $18 \quad(2)$ & $(3)^{a}$ & $18(5)^{a}$ \\
\hline Pediococcus & 2 & $17(2)^{a b}$ & $18 \quad(3)$ & $(3)^{a}$ & $23(10)^{a}$ \\
\hline Propionibacterium & 5 & $10(3)^{a}$ & (6) & $(7)^{a b}$ & $15(7)^{a}$ \\
\hline Streptococcus & 31 & $40 \quad(4)^{c}$ & $18 \quad(7)$ & $(5)^{b}$ & $(9)^{b}$ \\
\hline
\end{tabular}

*Bacteria $\left(5 \times 10^{8} \mathrm{CFU} \mathrm{ml}^{-1}\right)$ were incubated for $24 \mathrm{~h}$ at $25^{\circ} \mathrm{C}$ in corn infusion, $\mathrm{pH} 4$, containing ZEN, $5 \mu \mathrm{g} \mathrm{ml}^{-1}$, DON, $5 \mu \mathrm{g} \mathrm{ml}^{-1}$, and a mixture of $\mathrm{FB}_{1}$ and $\mathrm{FB}_{2}, 5 \mu \mathrm{g} \mathrm{ml}^{-1}$ each. Each strain was tested for each mycotoxin in duplicate.

"Values are the means (SD) of mycotoxin bound for all strains belonging to the same genus. Data within a column with unlike letter are not significantly different $(p<0.05)$.

${ }^{\ddagger}$ To show only binding, strains biotransforming ZEN were not included. 
Table IV. In vitro binding of zearalenone, deoxynivalenol, and fumonisins $\mathrm{B}_{1}$ and $\mathrm{B}_{2}$ by Lactobacillus species*

\begin{tabular}{|c|c|c|c|c|c|c|}
\hline \multirow{3}{*}{$\begin{array}{l}\text { Lactobacillus species } \\
\text { L. acidophilus }\end{array}$} & \multirow{3}{*}{$\begin{array}{c}\text { Number of strains } \\
7\end{array}$} & \multicolumn{5}{|c|}{ Fraction bound $(\%)^{\dagger}$} \\
\hline & & $\overline{Z E N^{\ddagger}}$ & \multicolumn{2}{|c|}{ DON } & FB1 & \multirow{2}{*}{$\frac{\mathrm{FB} 2}{22(10)^{\mathrm{abc}}}$} \\
\hline & & $19 \quad(4)$ & 22 & $(4)^{c}$ & $13(6)^{b}$ & \\
\hline L. brevis & 5 & $20 \quad(1)$ & 19 & $(5)^{c}$ & $9(4)^{a b}$ & 27 (9) ${ }^{b c d}$ \\
\hline L. buchneri & 3 & $20 \quad(2)$ & 4 & (4) ${ }^{\mathrm{ab}}$ & $11(1)^{a b}$ & $28(12)^{\mathrm{cd}}$ \\
\hline L. casei. subsp. alactosus & 1 & $18 \quad(0)$ & 10 & (0) ${ }^{\mathrm{abc}}$ & $3(0)^{a}$ & $9(0)^{\mathrm{a}}$ \\
\hline L. casei. subsp. casei & 21 & $18 \quad(4)$ & 17 & $(9)^{c}$ & $11(5)^{a b}$ & $25(11)^{\text {bcd }}$ \\
\hline L. casei. subsp. rhamnosus & 4 & $18 \quad(6)$ & 19 & $(6)^{c}$ & $12(7)^{a b}$ & $13(3)^{a b}$ \\
\hline L. delbruekii. subsp. bulgaricus & 5 & $28 \quad(4)$ & 11 & (9) ${ }^{\mathrm{abc}}$ & $12(5)^{a b}$ & $26(7)^{b c d}$ \\
\hline L. delbruekii. subsp. lactis & 3 & $22(5)$ & 19 & $(9)^{c}$ & $9(4)^{a b}$ & $23(9)^{a b c}$ \\
\hline L. fermentum & 10 & 21 & 13 & (8) ${ }^{a b c}$ & $13(12)^{b}$ & $25(11)^{\text {bcd }}$ \\
\hline L. helveticus & 8 & 19 & 17 & $(7)^{c}$ & $11(6)^{a b}$ & $31 \quad(9)^{\mathrm{cd}}$ \\
\hline L. jugurti & 7 & 19 (4) & 20 & $(9)^{c}$ & $12(7)^{a b}$ & $34 \quad(9)^{\mathrm{cd}}$ \\
\hline L. paraplantarum & 7 & $22(2)$ & 13 & (8) ${ }^{a b c}$ & $5(4)^{a b}$ & $10(6)^{a}$ \\
\hline L. pentosus & 1 & $23 \quad(0)$ & 2 & $(0)^{a}$ & $4(0)^{a b}$ & $32(0)^{\mathrm{cd}}$ \\
\hline L. plantarum & 46 & 19 & 13 & (9) ${ }^{\mathrm{abc}}$ & $9(5)^{a b}$ & $22(10)^{a b c}$ \\
\hline L. reuteri & 1 & $17 \quad(0)$ & 15 & (0) ${ }^{\mathrm{bc}}$ & $21(0)^{c}$ & $37(0)^{d}$ \\
\hline L. unidentified & 8 & $20 \quad(2)$ & 19 & $(9)^{c}$ & $8(5)^{a b}$ & $26 \quad(6)^{b c d}$ \\
\hline
\end{tabular}

*Test conditions were similar to those shown in table I.

${ }^{\dagger}$ Values are the means (SD) of mycotoxin bound for strains belonging to the same species. Data within a column with unlike letter are not significantly different $(p<0.05)$.

† To show only binding, strains biotransforming ZEN were not included. 
(a)
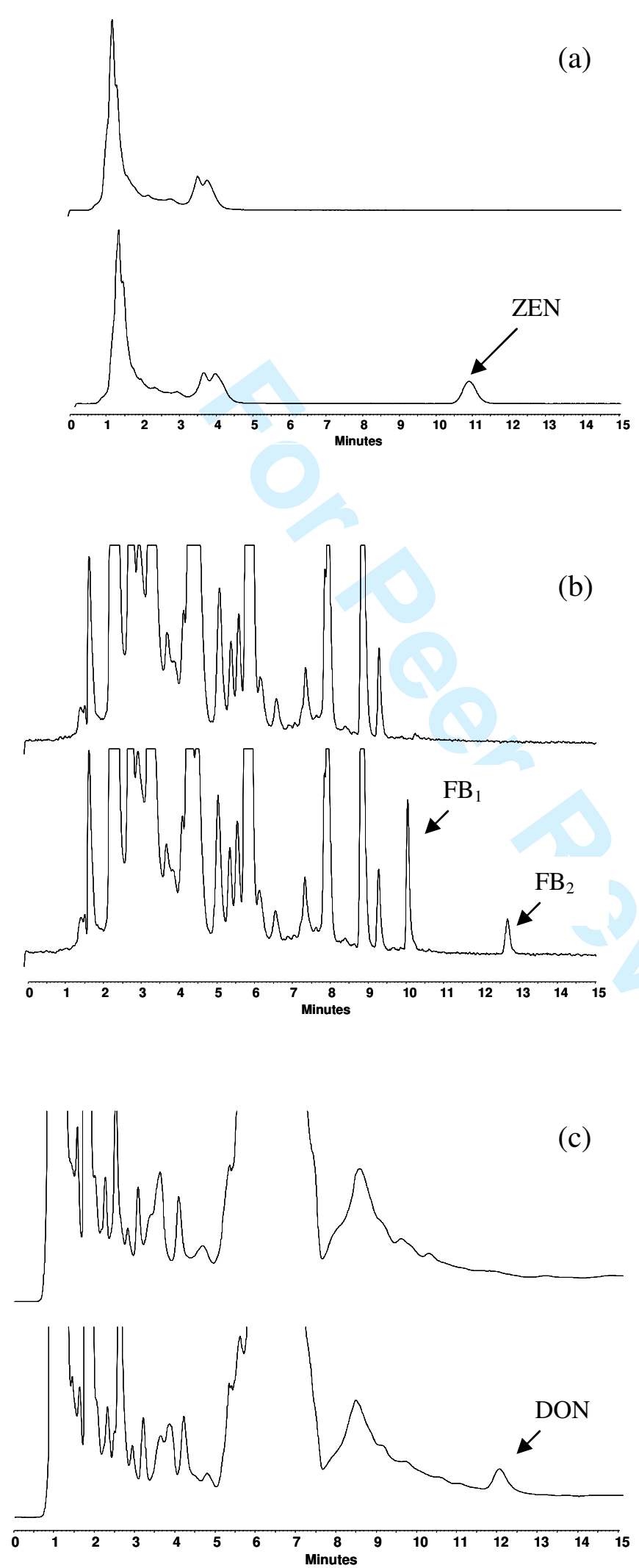

Figure 1. HPLC chromatograms of corn infusion supernatants incubated with bacteria $(5 \times$ $10^{8} \mathrm{CFU} \mathrm{ml}{ }^{-1}$ ) at $25^{\circ} \mathrm{C}$ for $24 \mathrm{~h}$ without and with zearalenone (ZEN, $5 \mu \mathrm{g} \mathrm{ml}^{-1}$ ) (a), without and with fumonisins $\mathrm{B}_{1}$ and $\mathrm{B}_{2}\left(\mathrm{FB}_{1}\right.$ and $\mathrm{FB}_{2}, 5 \mu \mathrm{g} \mathrm{ml} \mathrm{m}^{-1}$ each) (b), without and with deoxynivalenol (DON, $5 \mu \mathrm{g} \mathrm{ml}^{-1}$ ) (c). 
(a)

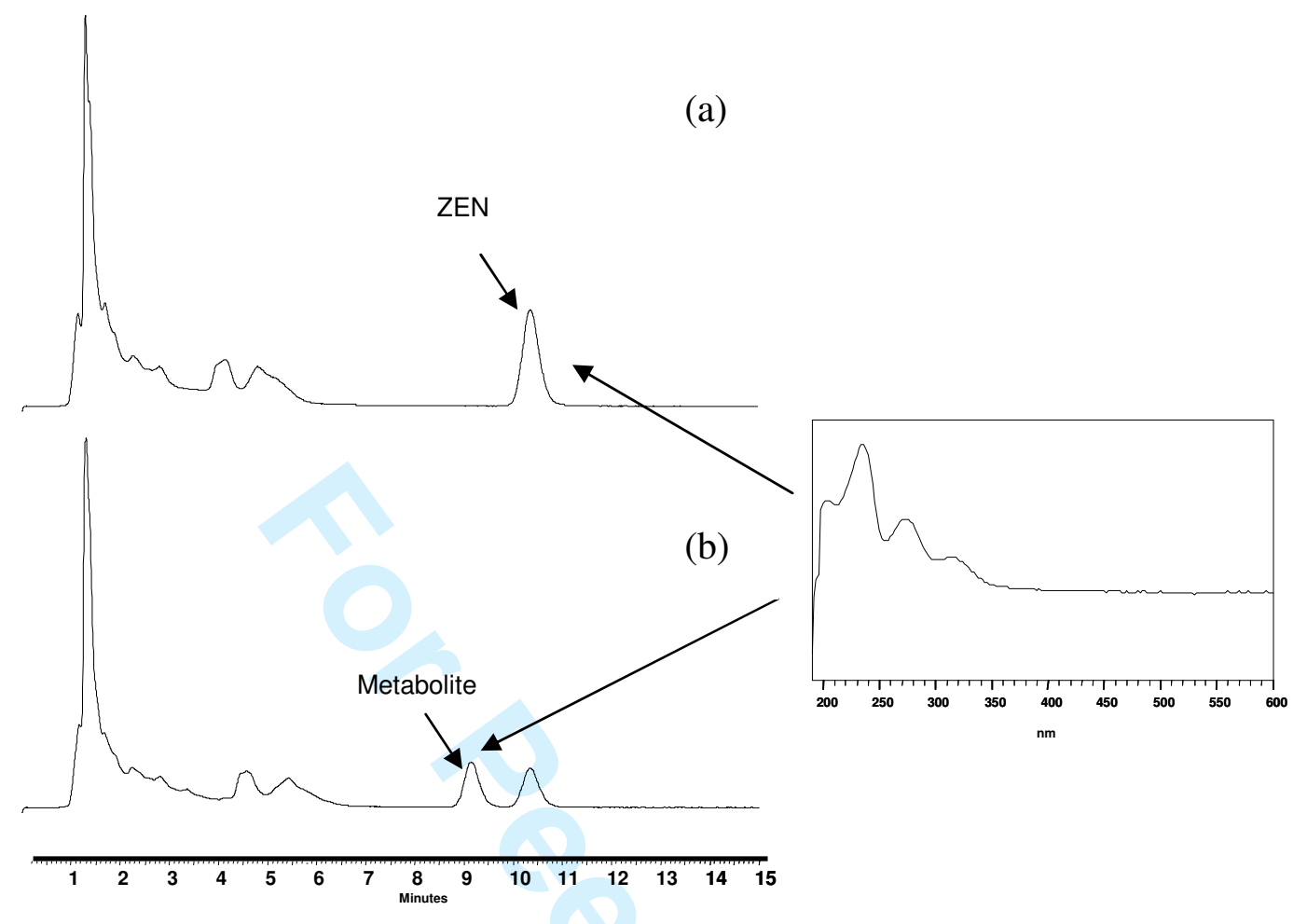

Figure 2. HPLC chromatograms of corn infusion supernatants containing zearalenone (ZEN, $5 \mu \mathrm{g} \mathrm{ml}^{-1}$ ) incubated at $25^{\circ} \mathrm{C}$ for $24 \mathrm{~h}$ without bacteria (a) and with Lactobacillus brevis $\mathrm{R} 0002\left(5 \times 10^{8} \mathrm{CFU} \mathrm{ml}^{-1}\right)(\mathrm{b}) . \mathrm{ZEN}$ (retention time $\left.=10.4 \mathrm{~min}\right)$ and metabolite (retention time $=9.2 \mathrm{~min}$ ) showed a similar UV spectrum (inset). 

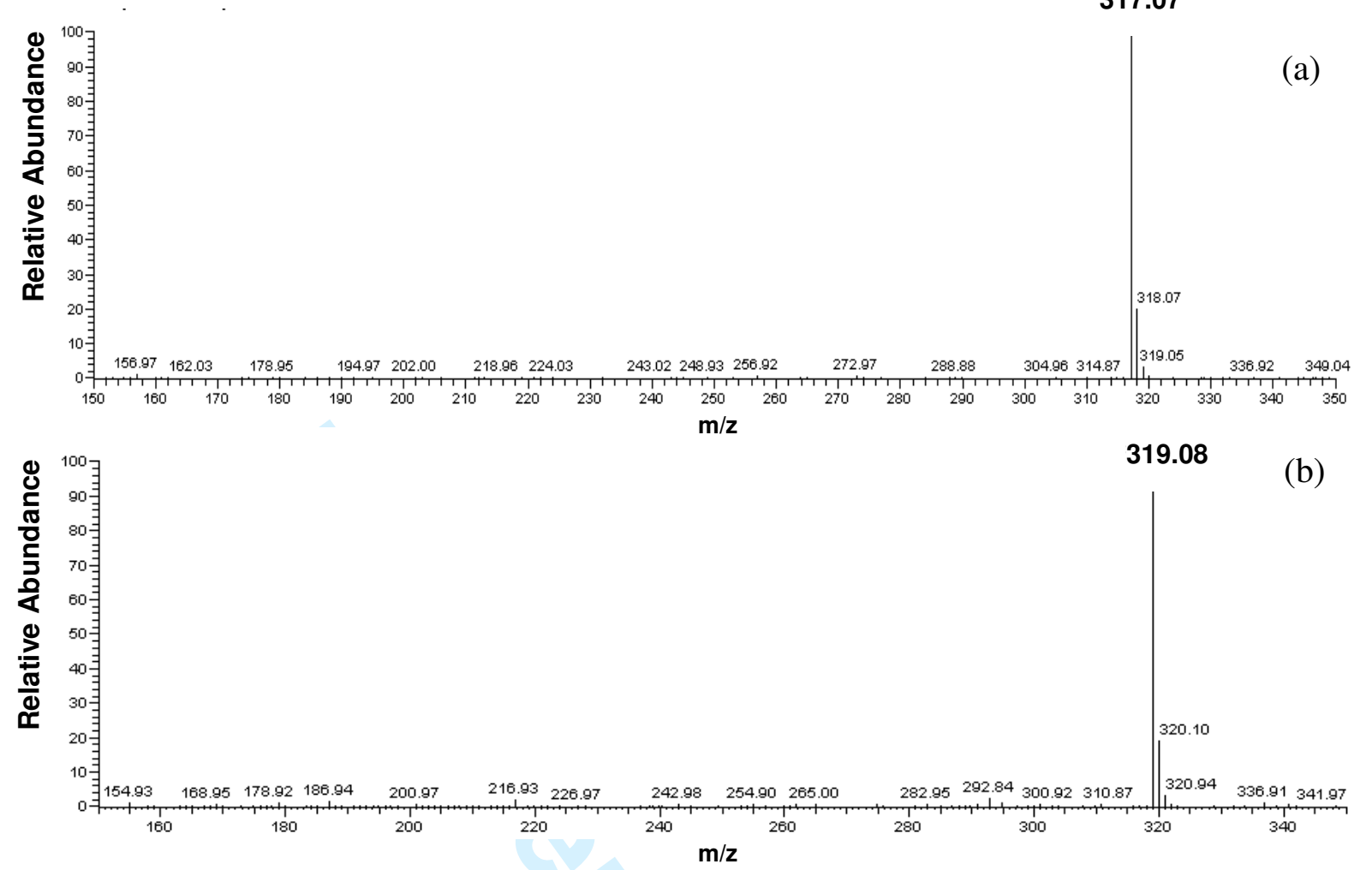

(c)

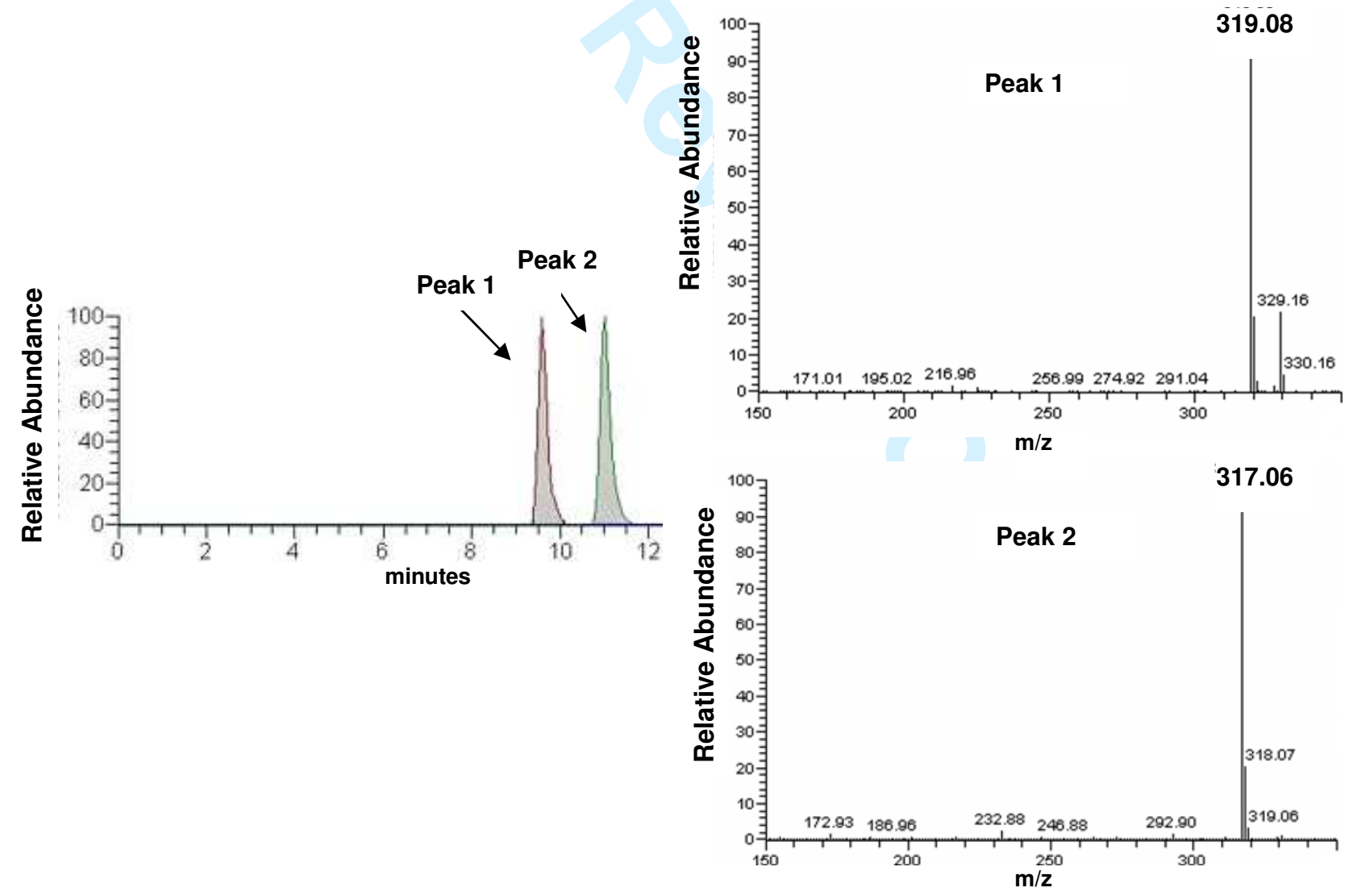

Figure 3. HPLC-MS spectra of zearalenone, ZEN (a) and $\alpha$ zearalenol, $\alpha$ ZOL (b) standards alone, and the extract from corn infusion supernatant containing ZEN and the produced metabolite (c). Spectra of peaks 1 and 2 showed parent mass of m/z 319.08 and 317.06, respectively. 